\title{
Josephine Butler's Serial Auto/biography: Writing the Changing Self through the Lives of Others
}

\section{By Rebecca Styler}

One aspect of the turn towards relationality in life writing studies, and its correlative erosion of the self-other binary, is a recognition of the porous boundaries between the biographer and their subject, and therefore also between the genres of autobiography and biography. The self-reflexive dimensions of the biographer's project have often been noted, Humphrey Carpenter going so far as to quip 'I've spent the last two decades trying to discover who I am through all the people I've been writing about' (273). Josephine Butler, a pioneering feminist reformer of late nineteenth-century Britain, was also a serial biographer and this article considers how she worked out her own (unconventional) vocational identity through writing the lives of others. Butler wrote six monographs and a number of shorter biographical sketches of fellow-campaigners, and my focus is on the two biographies she wrote during the early years of her controversial career, Memoir of John Grey of Dilston (1869), and Catharine of Siena (1878). In these vital years of establishing herself as leader of the campaign against state-regulated prostitution, it is in these works that Butler forges spiritual and political self-understandings that were to be the basis for her exceptional mission.

This is not an entirely new approach to Butler's biographical writings. Pat Starkey makes the valid general point that there is a dimension of 'self-making' in all of Butler's biographies, injected as they were with her own political and religious values, with cursory attention to each example. Janet Larson's intelligent study reads Butler's Catharine of Siena as a feminist auto/biography through which Butler vindicates female leadership at a point when this principle was under threat within her own campaign movement. Helen Rogers includes John Grey as an example of filial biography by radical daughters who found empowering role models in their reformist fathers' lives. What these studies of Butler's isolated works do not address is why Butler sought such different role models in the decade or so when she was establishing her public career, turning 
from the nineteenth-century male liberal reformer and family member to a medieval Roman Catholic female saint. Only by considering these works in conjunction can the contradictory self-understandings implied in these two works be appreciated as stages in Butler's evolving sense of her public selfhood, and her identification with the very different reform traditions these two subjects represent. While Rogers argues the potency of John Grey as exemplary biography for a radical daughter, I point to its ultimate failure to work for Butler, as she abandons the genderless ideal of the liberal reformer to adopt, in Catharine of Siena, the model of the female prophet-leader who is powerful not in spite of her sex (as Larson's reading tends to suggest) but because of it. Furthermore, Butler also left a large body of unpublished letters, the contents of which shed light on her use of the biography as a vehicle of self-construction, and some of these are read here alongside her published works. A comparative study of Butler's first two major biographies tells us much about this remarkable woman's serial self-construction in relation to nineteenth-century reform traditions and gender discourse, and signals an important strategy in Victorian women's life writing, while pointing to more general possibilities of considering an author's multiple biographies as a project of developmental self-production.

\section{Auto/Biography and Victorian Women's Life Writing}

Certainly since the 1990s, commentators on biography have recognised biography's subjective dimensions, and the author's self-investment in the narration they are creating from historical materials. Given that no writer has direct access to their subject's lived experience, and that all textual representations of reality are subjective and partial, a biographer's work is to construct a coherent narrative from textual sources that themselves are 'inherently unreliable', and might contain 'a fictional or reinvented element' (Holmes 17). Just as autobiographers shape the messy material of personal experience into a coherent narrative, thus creating a 'metaphor of the self' as James Olney famously termed it, so the biographer exercises hermeneutic control over the records of another's life and shapes it into a meaningful pattern through selection, sequencing, emphasis, evaluative commentary, 
contextualisation and rhetorical embellishment. Hence, 'The biographer is an active agent in the biographical process, in the sense that she constructs the biographical subject rather than merely represents them "as they really were"' (Stanley 9; see also Furbank 22-4). Interpretive agency is at work to the degree that not only can different writers produce different 'lives' from the same body of historical material, but even one author can imagine producing 'several completely different lives of the same person' from the same sources, organised by a different theme (Tridgell 31, Carpenter 274).

To this creative exercise, biographers bring their own psychological and political agendas, expectations, matrices of knowledge, and preconceptions, so that the pattern imposed on the biographical materials manifests their shaping intelligence. Biographers and critics alike have recognised this self-reflexiveness, and the possibility therefore of seeing biography as a form of 'displaced autobiography' since '[i]n what the biographer-personae reveal about their subjects, they evoke, reflect, and reveal themselves to their reader' (Holmes 24, Helms 343; see also Kendall 14-16). The very choice of subject as well as the arrangement of material reflects writers' aspirations, ideals and struggles, so that the hard and fast boundary once established between biography and autobiography is now considered blurred: biography is no longer understood as a narrative in which author and protagonist do not coincide (LeJeune 4-7), but rather as a work that manifests the imaginative interplay between writer and subject. Moreover, this intersubjectivity is not a one-way superimposition of the author's ideas onto inert material: just as autobiographical writing is a selfconstructive process, so the biographer is in some way dissolved or transmuted by the life he brought back to life' (Holmes 22). Through the shaping of another's life into a story, the biographer forges self-understandings, perhaps finding the displacement strategy valuable for self-analysis. Another advantage offered by self-reflexive biography is, like the autobiographical novel, the opportunity to express wish-fulfilment, since 'events occurring outside the range of the authorhero may be evoked and imaginatively relived' (Pascal 164) - certainly true of Butler whose subjects encounter enormous success in reforming the public sphere, at a time when Butler was embarking on a campaign that was to take up decades of her life. Helms summarises what can be gained from reading 
biography as an indirect form of autobiography: 'By shifting the focus of biographical analyses to the biographer-personae, we recognize and emphasize the importance of biographers' own self-definitions, self-creations, and the coming to terms with themselves in the process of writing someone else's lifestory' (Helms 344).

Despite this recognition, scant attention has been given to the possibilities of auto/biography being a serial activity. In the light of postmodern ideas of the self as fragmentary and constantly in transition, autobiography has been recognised as an account of various 'selves' that, left behind in the past, are 'other' to the narrating 'I' (Eakin 93). Yet this understanding is rarely applied to the work of biography, studies of which tend to focus on single works by individual writers, so the construction of self/other is analysed in relation to only one temporal manifestation. What merits further attention is the work of those who write biography serially, expressing their developing selfunderstandings over time.

Reading biography as 'displaced autobiography' is a particularly valuable approach to life-writing by nineteenth-century women, who, as a number of scholars have shown, tended to avoid the classic autobiographical narrative to express selfhood 'in a disguised form' through various literary modes (Sanders 3; also Peterson 121). Feminist scholars also emphasise that, over three centuries of women's life writing, selfhood has typically been articulated in relational terms, as the self embedded in another, often maintaining that it is characteristic of women to write their stories through the stories of others' (Yalom 63). Some studies have begun to explore the self-reflexive dimensions of Victorian women's biography, from collections of short exemplary lives which speak to contemporary debates about women's role (see Booth), to monographs in which authors explore their own professional/creative struggles through narrating another's (such as Elizabeth Gaskell's 1857 Life of Charlotte Brontë and Anna Thackeray Ritchie's 1881 Madame de Sévigné: see Helms and MacKay respectively). All these register the need to negotiate ambition, or vocation, with the demands of conventional codes of femininity, and Butler's writings can be read in this context. 
Given her exceptional public career, and her substantial oeuvre of writings including feminist polemic and theology, Josephine Butler can hardly be accused of lacking the self-confidence or the hermeneutic skill needed to author her own life narrative - some have even accused the reformer of 'egocentricity' (Starkey 136). That Butler did not pen her own autobiography, as did pioneering contemporaries such as Harriet Martineau (1877), Annie Besant (1893), and Frances Power Cobbe (1894), is one of the intriguing 'might-have-beens' of feminist literary history. Pertinent to this omission are comments that Butler made towards the end of her life, in which she forbade her sons from permitting 'any biography to be written of me after my death' (letter 5.3.1903 to Fanny Forsaith). First, she argues that she has already presented herself in parts to the public through her biographies of father, sister and husband - 'proximate others' in Eakin's terms that present the self 'through the lens of its relation with some other key person' (Eakin 86). In these lives of others, Butler admits, 'there is necessarily a good deal of my own life and of my own thought', as she says is also true of her published 'history of the cause' (Personal Reminiscences of a Great Crusade). Butler shows an understanding that self-expression can occur through indirect means. Her second concern is over-exposure, reluctant for anyone to attempt to represent 'anything more of my inward life and thoughts'. As well as a preference for privacy, there is a principle at stake. '[T] he present is such a shouting age, such a self-advertising age, which seems to me removed from the spirit of Christ, and, in fact is to me almost disgusting'. Butler then criticises some Christian reformers' autobiographies which exult in how many miles were travelled and how many public meetings addressed on their missions, thinking that these boasts are 'in very bad taste' although 'the fashion of the age'. Here, Butler voices criticism of the immodesty of autobiography, not it seems due to feminine anxieties but to religious ones, since it remained a concern through the nineteenth century that autobiographical self-publicising was contrary to Christian humility (Marcus 15-17).

With this wariness of overt self-mythologising, Butler nonetheless achieves this through narratives of the lives of others which fill her writings, in which the boundary between self and other is habitually blurred. She was an avid reader of biography and autobiography, ranging from contemporary figures 
like Annie Besant to medieval saints such as St Theresa. In her letters she regularly compares herself to Bible characters, finding in figures such as Daniel, Joshua, Paul and Christ paradigms to frame her own experience as a spiritual warrior and national saviour. In this, she was undoubtedly influenced by typological habits of readings of the Bible that were common in Evangelical circles, whereby biblical characters were read as timeless spiritual symbols that could mapped onto a Christian's experience. Scholars have noted Butler's startling level of self-identification with the women whose numerous stories she reports in her campaign writings, whereby Butler aligns herself symbolically with fallen women as fellows in outraged womanhood, whether in sisterly solidarity or in a maternalistic appropriation of their experience (Mathers 48-9; Walkowitz 90-2). Given this ingrained habit of using others' life stories as vehicles of self-expression, it is impossible to imagine Butler writing a biography which was not deeply self-referential.

\section{Memoir of John Grey of Dilston and the Genderless Ideal of the Liberal Reformer}

When she wrote her first biography, Butler was just emerging onto the public stage as a feminist reformer and polemicist. She had become a vocal supporter of expanding women's education and employment opportunities, serving for a time as president of the North of England's Council for Promoting the Higher Education Of Women, before whom she delivered her first public speech. A leading petitioner for married women's property rights, she had already published the first of two books that placed her at the heart of the early women's movement: The Education and Employment of Women (1868) and Women's Work and Women's Culture (1869). While these make some claims for women's extended sphere on the basis of their traditional specialisms in nurture and compassion, they prevailingly make the liberal egalitarian argument against the monopoly of privilege by the class 'which deprives, oppresses, or denies', positioning women as 'the class which is deprived, oppressed, or denied' (Butler, Woman's Work ix). The woman question is presented as a matter of straightforward social justice. Butler's father John Grey (1785-1868) died in 
January 1868, aged 83, and Butler published his biography the following year. The biography is a warm tribute to the public and private man, but it is also an exercise in self-definition, through which the author places herself in a family tradition of reformers, and thereby positions her feminism as an extension of nineteenth-century liberalism. John Grey was a substantial landowner in Northumberland, an internationally renowned agricultural reformer, and a political Liberal who became a public figure of note involved in numerous reform causes. Butler shows him connected to all the major liberal causes of the first half of the nineteenth century - supporting civil and religious liberties, free trade, national education, electoral reform in 1832, and the abolition of slavery in North America and the British colonies. As much as she recounts her father's life and work, Butler goes into detail well beyond her father's involvements, in a sense telling the story of the liberal spirit of the first half of the nineteenth century, with which she implicitly identifies herself.

As Helms shows in her discussion of Gaskell's biography of Charlotte Brontë, the author's persona is present within a biography in its rhetoric of interpretation, approval or defence of the subject's life events (Helm 344-5). The coherent theme Butler reads through all her father's causes is the erosion of monopolies on power, resources and personal liberty, and an ongoing mission to extend these privileges to an increasingly inclusive commonwealth. Grey's theme was to oppose the 'imposition of social disabilities of any kind, by one class of persons on another', the same schema of oppressor/oppressed in which Butler frames her critique of gender inequality (Butler, John Grey 47-8). Descriptions of the sufferings of the English poor at the hands of Tory landowners through trade protectionism, of slaves at the hands of their white masters, of the Irish poor at the hands of colonial rulers during the famine, reiterate the same polarised schema. In the context of the repressive 1810s and 20s, Butler shows Grey as a defender of personal liberty and champion of free speech: 'God made him a Liberal' she announces $(34-5,47)$. She charts a history of gradual liberalisation starting with the 1832 Great Reform Act, in terms that echo the rhetoric of the French Revolution - 'the new era, the year one of the people's liberties' (125). Furthermore, Butler explicitly aligns her father with the social gospel, naming his favourite Bible text as a passage from Isaiah that she often quoted in her own 
writings: 'Is not this the fast that I have chosen: to loose the bands of wickedness, to undo the heavy burdens, and to let the oppressed go free, and that ye break every yoke?' (49; see Education 33). Equating salvation with social justice, Butler understood her own campaigns as acts of spiritual warfare, and reads her father's actions in similar terms, claiming that 'he had sometimes to overcome prejudice, to meet opposition, and endure obloquy, throughout which he held on to his even and honourable cause', although she supplies virtually no evidence to support this image of martyrdom (154). While it could be said that she followed in her father's footsteps, as modern biographies of Butler tend to emphasise, citing John Grey as factual evidence (e.g. Jordan 9-11), it is equally fair to say that Butler retrospectively constructs her father in her own likeness.

This self-projection also involves Butler 'feminising' Grey to some degree, in emphasising his motives of concern for individuals in need. His philanthropy and activism she attributes, more than to any abstract political principle, to his 'large benevolence, his tender compassionateness, and his respect for the rights and liberties of the individual man. ... [H] e could not endure to see oppression or wrong of any kind inflicted on man, woman, or child' (47). She gives examples of him taking a particular interest in the wellbeing of women on his estates, helping them escape poverty and marital abuse, with a tendency to take the woman's part in disputes (329-30). These kinds of attentions were a form of philanthropy Butler had classed as distinctly womanly in her own polemic: 'It will always be in her nature to foster, to cherish, to take the part of the weak ... to have a care for individuals', a capacity attributed to women's innate 'maternal character' (Education 20-1, Woman's Work lx). In addition, with an eye to the prostitution campaigns on which she was about to embark, she emphasises her father's ideals of sexual 'purity' (337-9) as justification for attacking the sexual double standard. Butler constructs Grey as a character who transcends traditional gender distinctions, uniting masculine agency and scope for influence with a feminine moral sensibility, suggesting that this union forms the ideal reformer. In this way, the apparently deferential 'dutiful daughter' biography could be transformed, as Rogers argues, by radical Victorian women into a source of 'authority not anxiety' for the daughter's own ambitions: 'the father could 
represent an exemplary role-model for their own and their readers' private and public behaviour' (Rogers 148).

However, Butler does not only construct her father as a role model, but generates a family myth into which she writes herself, both implicitly and explicitly. She describes the Greys generally as 'so many hearts endowed with that strength of feeling which prepares for its possessors no easy or tranquil path to walk in' (189), called to be large hearted reformers passionately fighting structures of oppression, a voice for the voiceless, agents of God and humanity in the vanguard of social progress. Butler overtly inserts herself into this tradition in the penultimate chapter, when she describes herself enlisting her father's support in her campaign for women's property rights. Continuing the biographical narrative voice by referring to herself in the third person as 'one of his daughters', she evades the appearance of self-advertisement (328), while strategically positioning her work as an extension of her father's theme. If, as Rogers argues, biographies of political fathers provided an acceptable means for women to write political history (145), even more importantly it provided Butler with the opportunity to write herself into it. By finishing her narrative with an account of her father lending willing support to her campaigns, Butler suggests that her feminist activism is a continuation of the same principles he lived by, the next logical chapter in the narrative of liberal progress. She presents his openness to feminist causes as inevitable: 'He had indeed been so long accustomed to give his wife and daughters a share in, and to confer with them on all matters of interest and importance, political, social, and professional, as well as domestic, that to him it did not appear at all strange that women should rise up and claim a higher education, and a share in all the graver and more important work of life' (327). The scene describing her father signing the married women's property bill with which she presents him suggests a man, full of years, passing on the mantle of the liberal cause to its next champion (328-9). Only his death scene is left to narrate - the family vocation continues unbroken, sex difference no obstacle, her father's blessing her vindication. Butler creates a gender-blind model of the liberal reformer, which she adopts as her inheritance, suggesting optimistically that her feminist cause is an organic extension of the liberal progressive spirit of the age. 
Yet, I suggest, the concern that gender could complicate this purportedly genderless ideal is registered within the text itself, not in its protagonist but in the form of a minor character who can be interpreted as Butler's alter ego - the repressed radical woman, Grey's sister Margaretta. Butler introduces this figure with a sympathetic interpolation regarding her aunt's experience of female sex as a social disability:

I cannot look through the relics of her which have fallen into my hands without feelings of sadness. She became early conscious of mental power, and, even when a child, complained of the imperfect means of education open to her sex. ... There is evidence in her writings of some sore and secret rebellion at times against the limitations of her woman's estate, and the hindrance to the use of powers which she felt within her. ... Her sentiments at that time were revolutionary! (14-15)

The emotive rhetoric suggests a degree of identification on Butler's part - the aunt certainly has a greater place in the biography than her own mother does. Margaretta crops up again and again in the biography encouraging her brother in his causes, and Butler quotes her writings more than is strictly necessary to furnish the narrative, allowing Margaretta's voice to intervene with informed opinions on numerous public matters while unable to implement these views beyond supporting her more privileged brother (171, 197-8, 229-31, 242). Rather like Virginia Woolf's imagined fate for 'Shakespeare's sister', Margaretta is a picture of female talent wasted due to arbitrary cultural restrictions. While Butler implies historical distance between herself and the impotent female, as if gender roles have liberalised enough by 1869 for sex no longer to be an obstacle to public participation, the figure of Margaretta haunts the narrative as a marginalised female in ways that suggest no complacency on Butler's part, anticipating her next move in auto/biography. Her identification is not univocally focused on the successful father, but divided between his image and that of the failed female radical stifled by social restrictions.

\section{Prophetic Outsider and Mother of Humanity: Catharine of Siena}


Butler's second major biography marks a thorough loss of optimism about the possibility of female public vocation being normalised through the genderneutral model of the liberal reformer. Butler turns to a specifically female role model, intensely conscious of gender as a factor in her pioneering public work that can no longer be subsumed into a genderless appropriation of the model of the male reformer. Liz Stanley suggests that the archetypal narrative of autobiography is the Bildungsroman, 'the tale of the progressive travelling from troubled or stifled beginnings; in which obstacles are overcome and the true self actualised or revealed; and then the tale may, prototypically, end, or it may go on to document yet further troubles turned triumphs' (Stanley 11). Reading biography as displaced autobiography, it is Catharine of Siena, rather than John Grey of Dilston, that is Butler's bildungsroman given it charts the obstacles that have to be overcome to actualise the woman spiritual-political leader; it presents a paradigm not only for Butler to make sense of her own life journey, but potentially for other reform-minded women to adopt for theirs.

After her father's death, her campaign against the Contagious Diseases Acts revealed to her the deep, ideologically invested conflicts of interest that put paid to the hope that women's oppression could be addressed adequately through an organic extension of the liberal cause. The acts, aimed to protect men's sexual health by imposing examinations on women suspected of being prostitutes and imprisoning them if infected with venereal disease, were seen as a gross injustice by Butler. Perceiving them as an attack on women's constitutional rights to personal liberty, she also attacked them as a manifestation of the sexual double standard which tolerated male promiscuity while demonising 'fallen women', and of women's miserable lack of employment opportunities. In her lecture tours around Britain (1870-1) and Europe (where similar legislation had been passed, 1874-5) that broke the mould for women's public speaking, Butler addressed mixed audiences in many urban centres and presented evidence to a Royal Commission on the Acts. Butler accused the government of class-based and misogynistic exploitation, reducing women to the legal status of slaves, and attacked church leaders like Benjamin Jowett for remaining silent on the matter and even endorsing the acts as a regrettable necessity. She stirred deep hostilities among those with vested interests in 
retaining the status quo, at times incurring physical danger - the building in which she was speaking in the 1872 Pontefract bi-election to promote a proRepeal candidate was set on fire (see Jordan 137-40). The campaign took its toll on her psychologically, hearing repeatedly of abuses perpetrated on women and children that made her feel 'really ill', unable to report them even to her sister in personal correspondence (letter 5.2.75 to Harriet Meuricoffre); 'I have been in hell' she wrote some years later, looking back at her career (letter 2.4.05 to Harriet Meuricoffre).

Butler's language of the period is full of the rhetoric of spiritual warfare, pitting herself against a spiritual enemy which she saw within the structures of society, supported even by much of its liberal progressive element. This work inevitably required considerable inner strength and self-belief, and demanded a more powerful role model that would authorise specifically female activism against a patriarchal masculine establishment, working from outside the structures of power rather than - as John Grey broadly did - within them. Catherine of Siena provided for Butler the role model of a woman visionary, prophet and reformer, who was appointed by God to save the afflicted and correct the errors of temporal and ecclesiastical authorities, on the basis of her special qualities as a woman.

While it was unusual, it was not exceptional, for a nineteenth-century Protestant woman to take up a Roman Catholic saint for exemplary purposes Joan of Arc was the subject of a number of biographies, her individualistic stance against corrupt authorities suiting Protestant as well as feminist sensibilities. As Eileen Yeo suggests, female saints offered a 'divinely sanctioned active public role for women' (132) that went beyond the limited role models provided by women of scripture, and Anna Jameson's popular series Sacred and Legendary Art (1848-52) had done much to persuade Protestant readers to view saint legends sympathetically as symbols of spiritual virtues, even if not ascribing to them the mediating role granted by Catholic doctrine. Butler herself suggested that women were 'the greatest sufferers by the loss' of a female saint tradition suppressed through the Protestant terror of 'idolatry' (qtd in Larson 464). Butler's independent and eclectic reading included the writings of saints whose intense, visionary communications with God resonated with her own: she greatly 
admired Quakers' faith in the 'inner light' and their 'habit of communion with God' (letter April 1977 to Catty), and records in some of her letters intense prayer sessions in which she senses 'glorious thoughts, not my own, but given to me' (letter 28.11.03 to Fanny Forsaith). Because of this independent, intense sense of direct communication with the divine, several have described her 'a mystic', including her own grandson (A.S.G. Butler 173, Neal 159-62). Butler declared reading St Theresa's 'The Life of Prayer', an account of dialogues with God, to be an 'an epoch' in her own life, continuing to find fellowship with the author in later years (e.g. letter [4.6.98] to Fanny Forsaith). As well as identifying with their intense intimacy with heaven, Butler was also drawn by female saints' heroic aspect, once recommending a discouraged supporter in Paris to go and contemplate a painting in the Louvre showing 'St Margaret the patron saint of purity, trampling down the hideous dragon, \& looking so calm and peaceful' (letter 1.3.75 to Aimé Hubert ). Here the saint is for Butler a 'type' of woman as the pure and pacific power that could defeat the powers of darkness. '[S]omewhat purged of their Roman Catholic theology and context', and remodelled 'in Butler's own image' (Neal 158), saints could mirror Butler's sense of her own exceptionality as a specially endowed spiritual warrior.

What Catherine offered, more than Theresa, was a figure who was both visionary and activist, and whose spiritual vocation led to an astonishingly public career for a woman of her time. Daughter of a wool-dyer, Catherine (c. 1347-80) claimed to have visions from the age of 6 , refused marriage, and after a 3-year period of self-seclusion felt called to serve the sick and poor of Siena. At first under the aegis of the Dominican order, she gathered around her a group of followers, and became involved in politics as she negotiated between anti-Papal civic authorities in order to restore unity in the church, calling the Pope back to Rome from his self-exile in Avignon. Her literary legacy includes the Dialogues (records of her communications with heaven), and an abundance of letters to popes, cardinals, bishops, monks, monarchs, civic leaders, aristocratic women, lawyers, artists, disciples and family members (see Parsons 6-9). The quantity and variety of materials available regarding Catherine meant that any attempt at narrating the saint's life would inevitably involve considerable opportunities for selection and construction (Butler notes in her introduction over forty 'Lives' of 
Catherine available in Latin, Italian, German, French, Dutch and Spanish, many of which she was equipped to read in their original). Scholars of Catherine's cult acknowledge that 'she presents many different "faces"', being 'reproduced' and 'recreated' in different contexts to serve altering ideals (Hamburger and Signori 1, 13; see also Parsons 4, 9-13). While her early cult made her a model of the ascetic and contemplative life, partly in deference to conventional estimates of female piety, in the twentieth century a 'distinctly political Catherine' was normalised, one which first began to emerge in the context of the Italian resorgimento as patron of 'civil religion' (Hamburger and Signori 14; Parsons 14). While Butler's biography is absent from accounts of her cult, it was Butler's achievement to reclaim the radical Catherine and shape her as a philanthropist and politician, a campaigner and prophet, a mother of humanity and a critic of compromised Christendom.

By defining Catherine from the start as a prophet, Butler places her in the gender-specific reform tradition of apocalyptic feminism, a movement that centred millenarian hopes for radical social renewal on the emancipation of women, and the extension of 'womanly' sympathy and love to all social relations (Helsinger et al xv). This powerful reform discourse within Victorian feminism rests on essentialist notions of women's characters as morally and spiritually superior to men's, and Butler has been connected to this movement, and to the essentialist mode of feminism that underpinned it (Flammang 161, Daggers 1001, 105-7). Catherine is her icon of this reform tradition, a prophet of the exalted feminine who is the redeemer of her times not just despite, but because, of her sex. Butler elsewhere defended prophecy as a gender-inclusive role through which one who 'sees as God sees' is empowered to correct the 'false traditions' that govern the thought of the day (Prophets 5,6,9), but she also emphasises the role as one of compassionate identification with the oppressed: it is to such 'generous souls ... beating in sympathy with the great heart of humanity ... that God gives insight, wisdom and the power to redress wrong' (Our Christianity 61). As Lucretia Flammang argues, Butler's notion of the prophet was of one who identified with 'the divine pathos' and committed themselves to enacting it (Abraham Heschel quoted in Flammang 157-8), and in such terms Butler paints 
Catherine as a universal saviour figure, as "her heart embraced all the sorrows of earth' (182). She introduces Catherine from the start as a prophet:

'through the centuries ... there was never wanting a succession of prophets, who rose up one by one, to repudiate in the name of Christ and in the face of the world, the corruptions, follies, and crimes committed in the name and by the authority of the professed ministers of Christ's religion, the ecclesiastical rulers who had become, in fact, the ministers of injustice and oppression'. (13-14)

This pictures a more antagonistic relationship with the establishment than that enjoyed by the liberal reformer, critic not only of secular powers, but of the church, and champion of those in whose oppression Christendom itself colludes. The biography not only suggests Catherine as keeper of the flame and corrective of the Christian establishment, but implicitly positions Butler as her spiritual descendant.

In her portrayal of Catherine's visionary communications with God, Butler confronts the cultural obstacles to women's public ministry, focusing on the ways in which God overturns Catherine's internalised anxieties about the public mission she is being called to. When Catherine protests 'my sex is an obstacle' (66), she receives divine assurance through words of scripture that no Protestant contemporary of Butler's could contradict: 'I pour out the favour of my spirit on whom I will. With me there is neither male nor female' (Joel 2:28-9; Galatians 3:28). Moreover, God tells Catherine that a woman is preferred for his purposes, because she speaks from outside the structures of authority, presenting to ministers in the church 'a salutary and useful confusion, that they may acknowledge their error and humble themselves' (66-7). Detached from the powers that be, a woman's outsider status is itself a virtue, and source of counter-hegemonic power.

Eschewing the then-dominant image of Catherine as conventual contemplative, Butler presents her period of seclusion as a time of preparation for her true vocation, and quickly presses on to demonstrate Catherine's wideranging and active public work at first in her locale, and then in travels through 
Italy that reflect Butler's own controversial public lecture tour, culminating in Catherine's confrontation with the Pope at Avignon. Yet Butler recurrently presents these activities not as an appropriation of masculine roles, but as expressions of Catherine's innate motherliness, a strategy that not only makes her public action acceptable (echoing dissenting women preachers who claimed to be 'Mothers in Israel'), but also to claim a unique spiritual role for women on the basis of their essential virtues. Elsewhere Butler had briefly commemorated St Margaret of Cortona's attitude towards the poor as 'maternal' (Hour 54). According to record, Catherine's followers were known as her famiglia and called her mamma (Parsons 7), but Butler expands this domestic model to encapsulate all her public activities. Catherine's philanthropy is driven by the 'burning love of her heart for humanity', through which she becomes 'mother of humanity' and 'mother of many souls' (the latter phrase recalling and reapplying a medieval title for Christ) $(\mathrm{x}, 22)$. Catherine describes her mission as spiritual 'travail' comparable with other women's literal experience of childbirth (184-5). But it is not just public charity that is reclaimed as motherly, for Catherine overcomes her fears about the propriety of public speaking because 'her maternal heart was moved to its depths' as she looked upon her disconsolate listeners (142). The saint's success as peacemaker and diplomat, negotiating with princes and prelates, are attributed to 'true womanly tact' (168), and her denunciation of church powers for their 'hollowness, hypocrisy and abominable vices' is delivered 'with the passionate pleading and tenderness of a woman whose soul is filled with Christian love and pity for her kind' (13). Catherine 'boldly and frankly' persuading the Pope to return to Rome from his self-chosen exile in Avignon is motivated not by a pious ideal of church unity, but by a conviction of the social gospel: like an Old Testament prophet she calls the religious establishment away from its worldly-mindedness to resume its appropriate 'poverty and humility' and remove its officers who 'devour the poor' (154-5). Catherine's success offers a strong dimension of wish-fulfilment given Butler's so-far frustrated activism against the Contagious Diseases Acts. Butler constructs a role model and empowering alter ego who is the best philanthropist, preacher, politician and critic of the church because of the compassion she claims as a specialism of the female sex. 
In an act of powerful displaced self-mythologising, Butler also makes meaningful to her own spirituality the episode - difficult for Protestants to accommodate - of Catherine receiving the stigmata. Butler manages this legend by emphasising its possible validity as a subjective experience that signified to the saint her 'perfect oneness with Christ' (133), noting that Catherine bore no external marks of crucifixion, only felt the imprinted wounds within. Butler suspends judgement on this 'mystery' and on prescribing limits on spiritual experience given the 'intensity of the outgoing of her soul towards God, or his deep and secret revelations of himself to her' (133). These comments seem deeply self-reflexive, in the light of Butler's description elsewhere of experiencing a sense of special wounding through which she identifies with the divine pathos' for humanity as Flammang describes it (see above). In her address The Hour Before the Dawn (1876) Butler relates: 'I asked of the Lord one thing that he would take of his own heart and show it to me ... so much of it as the finite can receive of the Infinite (for to know his love for the world and his sorrow for the world, as they are, would break any human heart), ... and when he makes this revelation he does more; he makes the inquiring soul a partaker of his own heart's love for the world' (97). This illustrates what Lisa Noland calls Butler's 'stigmatic consciousness' (268-9), so that Catherine's self-perceived bodily registration of Christ's crucifixion marks is symbolically coherent with the biographer's sense of her own exceptional call to participate in Christ's redemptive sufferings for the world.

Catharine of Siena, then, is Josephine Butler's bildungsroman in coded form, a deeply self-reflexive shaping of the life of a historical-legendary personage whose records could proffer numerous narrative possibilities, including exactly the unworldly contemplative piety to which Butler was opposed. Like women writers who used the lives of others to articulate their own struggles in reconciling authorship with the Victorian cultural codes policing womanhood, the reformer-campaigner used the life of one temporally and geographically remote from her own in order to analyse, vindicate and inspire her own spiritual leadership. The self-referential purposes that this auto/biography serves are highlighted when considered alongside Butler's earlier memoir, in which she attempts to define herself through, and locate 
herself in, a reform tradition whose essence was to overlook gender as a specific category of value. Catharine of Siena marks the failure of the paternal model of liberal reformer for Butler, and a recognition instead of the need to create a persona that found rhetorical and spiritual power within its oblique relation to the establishment. While in later writings she was prepared to allow men to have maternal motives in relation to society's vulnerable (Lady5), in the 1870s Butler embraced the essentialist discourse of apocalyptic feminism to claim unique spiritual authority for her second subject. The two works are best understood as a serial self-construction which registers Butler's changing political needs during this turbulent decade, exchanging one discourse of reform for another to make best sense of her role and her cause as it unfolded. This comparative attention to sequential biographies by one author demonstrates one example - perhaps among many potential others - of a writer for whom self-construction was a developmental, as well as displaced, practice.

\section{WORKS CITED}

Booth, Alison. How to Make it as a Woman: Collective Biographical History from Victoria to the Present. Chicago: Chicago University Press, 2004.

Butler, A.S.G. Portrait of Josephine Butler. London: Faber \& Faber Ltd, 1954.

Butler, Josephine. The Education and Employment of Women. Dodo Press, n.d [1868].

'Introduction.' In Woman's Work and Woman's Culture: A Series of Essays. Ed. Josephine Butler. London: Macmillan, 1869. vii-lxiv.

Memoir of John Grey of Dilston. Edinburgh: Edmonston \& Douglas, 1869.

The Hour Before the Dawn: An Appeal to Men. London: 1876. Catharine of Siena: A Biography. $4^{\text {th }}$ Edition. London: Dyer Bros, 1885 [1878].

Our Christianity Tested by the Irish Question. London: 1887. The Lady of Shunem. London: Horace Marshall \& Son, 1894. Prophets and Prophetesses: Some Thoughts for the Present Times. London: 1898. 
Letters. Josephine Butler archive, Women's Library, London

School of Economics.

Carpenter, Humphrey in conversation with Lyndall Gordon. 'Learning about Ourselves: Biography as Autobiography.' In The Art of Literary Biography. Ed. John Batchelor. Oxford: Clarendon Press, 1995. 267-79.

Daggers, Jenny. 'Josephine Butler and Christian Women's Identity'. In Sex, Gender, and Religion: Josephine Butler Revisited. Ed. Jenny Daggers and Diana Neal. New York: Peter Lang, 2006. 97-111.

Eakin, Paul. How Our Lives Become Stories: Making Selves. Ithaca, Cornell University Press, 1999.

Flammang, Lucretia A. "'And Your Sons and Daughters Will Prophesy”: The Voice and Vision of Josephine Butler'. In Women's Theology in Nineteenth-Century Britain: Transforming the Faith of Their Fathers. Ed. Julie Melnyk. New York: Garland, 1998. 151-64.

Furbank, P.N. 'The Craftlike Nature of Biography'. In Biographical Passages: Essays in Victorian and Modernist Biography. Ed. Joe Law and Linda K. Hughes. Colombia: University of Missouri Press, 2000. 18-27.

Hamburger, Jeffrey F. and Gabriela Signori. 'The Making of a Saint: Catherine of Siena, Tommaso Caffarini, and the Others - Introduction.' In Catherine of Siena: The Creation of a Cult. Ed. Jeffrey F. Hamburger and Gabriela Signori. Turnhout: Brepols, 2013. 1-22.

Helms, Gabriele. 'The Coincidence of Biography and Autobiography: Elizabeth Gaskell's The Life of Charlotte Brontë'. Biography 18:4 (Fall 1995): 339-59.

Helsinger, Elizabeth K., Robin Lauterbach Sheets, and William Veeder. 'Introduction'. In The Woman Question: Society and Literature in Britain and America 1837-1883. Ed. Elizabeth K. Helsinger, Robin Lauterbach Sheets, and William Veeder. 3 vols. Manchester: Manchester University Press, 1983. Vol.I Defining Voices. i-xvii.

Holmes, Richard. 'Biography: Inventing the Truth'. In The Art of Literary Biography. Ed. John Batchelor. Oxford: Clarendon Press, 1995. 15-25.

Jordan, Jane. Josephine Butler. London: John Murray, 2001.

Kendall, Paul Murray. The Art of Biography. London: George Allen \& Unwin Ltd, 1965. 
Larson, Janet. 'Josephine Butler's Catherine of Siena: Writing Autobiography as Feminist Spiritual Practice.' Christianity and Literature 48:4 (1999): 445-71.

Lejeune, Philippe. On Autobiography. Ed. Paul John Eakin. Trans. Katherine Leary. Minnesota, University of Minnesota Press, 1989.

MacKay, Carol Hanbery. 'Biography as Reflected Autobiography: The SelfCreation of Anne Thackeray Ritchie'. In Revealing Lives: Autobiography, Biography and Gender. Ed. Susan Groag Bell and Marilyn Yalom. Albany: State University of New York Press, 1990. 65-79.

Marcus, Laura. Auto/Biographical Discourse: Theory, Criticism, Practice. Manchester: Manchester University Press, 2006.

Mathers, Helen. “'Tis Dishonour Done to Me": Self-Representation in the Writings of Josephine Butler'. In Sex, Gender, and Religion: Josephine Butler Revisited. Ed. Jenny Daggers and Diana Neal. New York: Peter Lang, 2006. 37-53.

Neal, Diana. 'Flirting with the Catholic Other.' In Sex, Gender, and Religion: Josephine Butler Revisited. Ed. Jenny Daggers and Diana Neal. New York: Peter Lang, 2006. 155-71.

Nolland, Lisa Severine. A Victorian Feminist Christian: Josephine Butler, the Prostitutes, and God. Carlisle: Paternoster Press, 2004.

Parsons, Gerald. The Cult of Saint Catherine of Siena: A Study in Civil Religion. Aldershot: Ashgate, 2008.

Pascal, Roy. Design and Truth in Autobiography. London: Routledge \& Kegan Paul, 1960.

Peterson, Linda H. Traditions of Victorian Women's Autobiography: The Poetics and Politics of Life Writing. Charlottesville: University Press of Virginia, 1999.

Rogers, Helen. 'In the Name of the Father: Political Biographies by Radical Daughters'. In Life Writing and Victorian Culture. Ed. David Amigoni. Aldershot: Ashgate, 2006. 145-64.

Sanders, Valerie. The Private Lives of Victorian Women: Autobiography in Nineteenth-Century England. London: Harvester Wheatsheaf, 1989.

Stanley, Liz. The Auto/Biographical I: The Theory and Practice of Feminist Auto/Biography. (1996). Manchester: Manchester University Press, 1992. 
Starkey, Pat. 'Saints, Virgins and Family Members: Exemplary Biographies? Josephine Butler as Biographer. In Sex, Gender, and Religion: Josephine Butler Revisited. Ed. Jenny Daggers and Diana Neal. New York: Peter Lang, 2006. 135-53. Tridgell, Susan. Understanding Our Selves: The Dangerous Art of Biography. Bern: Peter Lang, 2004.

Walkowitz, Judith R. City of Dreadful Delight: Narratives of Sexual Danger in LateVictorian London. Chicago: Chicago University Press, 1992.

Yalom, Marilyn. 'Biography as Autobiography: Adele Hugo, Witness of Her Husband's Life'. In Revealing Lives: Autobiography, Biography, and Gender. Ed. Susan Groag Bell and Marilyn Yalom. Albany: State University of New York Press, 1990. 53-63.

Yeo, Eileen Janes. 'Protestant Feminists and Catholic Saints in Victorian Britain'. In Radical Femininity: Women's Self-Representation in the Public Sphere. Ed. Eileen Janes Yeo. Manchester: Manchester University Press, 1998. 127-48. 